\title{
Pemberian Ransum dengan Protein dan Kalsium Mikropartikel Ditambah Lactobacillus acidophilus atau acidifier terhadap Ketahanan Tubuh dan Bobot Karkas Broiler
}

\author{
Feeding a Ration with Protein and Calcium Microparticles Added with Lactobacillus \\ acidophilus or Acidifier on Immune System and Carcass Weight of Broiler
}

\section{O. N. Ain, N. Suthama dan B. Sukamto}

Fakultas Peternakan dan Pertanian Universitas Diponegoro Semarang Jln. Drh R. Soejono Koesoemowardojo, Tembalang, Kota Semarang 50275 Corresponding e-mail: nsuthama@gmail.com

\begin{abstract}
This study aimed to evaluate the effect of dietary microparticles protein and calcium with addition of probiotics Lactobacillus acidophilus or acidifier on lymphoid organ weight, heterophyl-lymphocyte $(\mathrm{H} / \mathrm{L})$ ratio and carcass weight of broiler chickens. A total of 160 broiler chickens of 15 -day old (body weight was $343.53 \pm 9.57 \mathrm{~g}$ ) were used in this experiment. The treatments applied were T0: (21\% standard protein feed), T1: (18\% intact protein feed $+1.2 \mathrm{ml}$ Lactobacillus acidophilus $\left(10^{8} \mathrm{cfu} / \mathrm{ml}\right), \mathrm{T} 2:(18 \%$ intact protein feed $+1.2 \%$ citric acid), T3: ( $18 \%$ microparticle protein feed $+1.2 \mathrm{ml}$ Lactobacillus acidophilus $\left(10^{8} \mathrm{cfu} / \mathrm{ml}\right)$, and T4: $(18 \%$ microparticle protein feed $+1.2 \%$ citric acid). The relative weights of lymphoid organs (bursa fabricius, thymus, spleen), H/L ratio and carcass weight were parameters measured. The present study was assigned in a completely randomized design with 5 treatments and 4 replications ( 8 broilers each). The data were analyzed by analysis of variance (ANOVA) at $5 \%$ probability level and completed with Duncan test. The results showed that feed added with citric acid as acidifier (T4) significantly $(\mathrm{P}<0.05)$ increased relative thymus weight $(0.22 \%)$, bursa fabricius $(0.18 \%)$ and spleen $(0.30 \%)$, with the highest carcass weight was in T0 $(1079.50 \mathrm{~g})$, but no effect on $\mathrm{H} / \mathrm{L}$ ratio. In conclusion, microparticle-composed feed containing $18 \%$ protein added with acidifier can maintain immune status based on the $\mathrm{H} / \mathrm{L}$ ratio, and increases relative bursa and thymus weights, but reduces carcass weight.
\end{abstract}

Key words: broiler, lymphoid organ, microparticle protein, acidifier, Lactobacillus acidophilus

\begin{abstract}
ABSTRAK
Penelitian ini bertujuan untuk mengkaji pengaruh ransum menggunakan protein dan kalsium mikropartikel yang ditambah probiotik Lactobacillus acidophillus atau acidifier terhadap organ limfoid, rasio heterofil-limfosit $(\mathrm{H} / \mathrm{L})$ dan bobot karkas pada ayam broiler. Ternak yang digunakan dalam penelitian ini 160 ekor ayam broiler umur 15 hari (bobot badan 343,53 9,57g). Perlakuan yang diterapkan yaitu T0:(ransum protein standar 21\%), T1: (ransum protein non mikropartikel $18 \%+$ Lactobacillus acidophilus $1,2 \mathrm{ml}\left(10^{8} \mathrm{cfu} / \mathrm{ml}\right), \mathrm{T} 2$ : (ransum protein non mikropartikel 18\% + asam sitrat 1,2 \%). T3: (ransum protein mikropartikel 18\% + Lactobacillus acidophilus 1, $2 \mathrm{ml}\left(10^{8} \mathrm{cfu} / \mathrm{ml}\right)$, dan T4: (ransum protein mikropartikel $18 \%$ + asam sitrat $1,2 \%$ ). Parameter yang diamati adalah bobot relatif organ limfoid (bursa fabrisius, timus dan limfa), rasio H/L dan bobot karkas. Penelitian disusun dalam rancangan acak lengkap (RAL) dengan 5 perlakuan dan 4 ulangan. Masing-masing ulangan terdiri dari 8 ekor ayam broiler. Data dianalisis ragam (analysis of variance) pada taraf $5 \%$ dan dilanjutkan dengan uji Duncan apabila perlakuan menunjukkan pengaruh nyata. Hasil penelitian menunjukkan bahwa perlakuan ransum protein mikropartikel $18 \%$ ditambah asam sitrat $(\mathrm{T} 4)$ nyata $(\mathrm{P}<0,05)$ meningkatkan bobot relatif timus $(0,22 \%)$, bursa fabrisius $(0,18 \%)$ dan limfa $(0,30 \%)$, dengan bobot karkas paling tinggi pada perlakuan kontrol (T0) $(1079,50 \mathrm{~g})$ namun tidak nyata terhadap rasio $\mathrm{H} / \mathrm{L}$. Kesimpulan penelitian yaitu pemberian ransum mikropartikel dengan protein $18 \%$ yang ditambah acidifier mampu mempertahankan ketahanan tubuh tetap stabil berdasarkan rasio $\mathrm{H} / \mathrm{L}$, dan meningkatkan bobot relatif bursa dan timus, namun menurunkan bobot karkas.
\end{abstract}

Kata kunci: broiler, organ limfoid, ransum mikropartikel, acidifier, Lactobacillus acidophilus

\section{PENDAHULUAN}

Ayam broiler merupakan unggas ransum yang berkualitas baik dengan pedaging yang menjadi prioritas sebagai penambahan additif yang aman dan bebas penghasil daging selain ternak ruminansia, untuk antibiotik diperlukan untuk meningkatkan memenuhi kebutuhan protein hewani. Pemberian pertumbuhan, performans dan immunitas ayam 
broiler (Yulma et al., 2014). Usaha untuk meningkatkan nilai nutrisi dan meningkatkan ketahanan kesehatan ternak unggas dapat dilakukan dengan cara penambahan bahan additif (Murtini et al., 2009). Efisiensi penggunaan bahan pakan sumber protein seperti tepung ikan dan bungkil kedelai dapat dilakukan dengan memperkecil ukuran partikel bahan pakan tersebut melalui pengolahan menjadi protein mikropartikel. Bungkil kedelai dan tepung ikan sebagai sumber protein dibuat mikropartikel dengan menggunakan gelombang ultrasonic dapat meningkatkan pemanfaatan protein dan kalsium (Suthama dan Wibawa, 2016).

Penurunan protein ransum dengan bahan sumber protein mikropartikel diharapkan dapat meningkatkan penyerapan nutrien menjadi lebih baik sehingga tidak memberikan dampak negatif terhadap ketahanan tubuh dan juga produktivitas (Harumdewi et al., 2018). Penyerapan kalsium lebih efisien pada saat usus dalam kondisi asam atau pH rendah (Yendy et al., 2014). Suasana asam pada usus dapat ditunjang dengan penambahan acidifier. Acidifier dapat berasal dari asam sitrat baik sintetis maupun alami (Onyeagba et al., 2004). Penambahan acidifier pada ransum bertujuan untuk mempertahankan kondisi $\mathrm{pH}$ saluran pencernaan dan menekan pertumbuhan mikroba patogen sehingga meningkatkan kesehatan saluran pencernaan sehingga penggunaan protein dan kalsium meningkat (Natsir, 2007).

Disisi lain penggunaan probiotik Lactobacillus sp. dalam campuran ransum dapat menghambat pertumbuhan bakteri patogen, meningkatkan pencernaan serta menetralisir enterotoksin dan menstimulir sistem kekebalan (Manin, 2010). Tujuan dari penelitian ini yaitu untuk mengkaji pengaruh protein dan kalsium mikropartikel yang ditambah dengan probiotik Lactobacillus acidophilus atau acidifier terhadap organ limfoid dan rasio heterofil-limfosit pada ayam broiler serta performans ayam broiler.

\section{MATERI DAN METODE}

\section{Ternak dan Ransum}

Penelitian ini menggunakan ayam broiler umur 15 hari sebanyak 160 ekor dengan bobot $343,53 \pm$ 9,57 g, Lactobacillus acidophilus 1,2 ml $\left(10^{8} \mathrm{cfu} / \mathrm{ml}\right)$, acidifier. Ransum untuk ayam broiler yang tediri dari Jagung giling, bekatul, tepung cangkang telur mikropartikel, bungkil kedelai mikropartikel dan non mikropartikel, tepung ikan mikropartikel dan non mikropartikel, premix dan $\mathrm{CaCO}_{3}$. Komposisi bahan pakan dan kandungan nutrisi ransum yang akan diberikan dapat dilihat pada Tabel 1.

\section{Pembuatan Protein dan Kalsium Mikropartikel}

Metode yang dilakukan untuk pembuatan kalsium mikropartikel yaitu dengan cara membersihkan limbah cangkang telur dengan air kemudian dikeringkan dibawah sinar matahari dan dibuat tepung dengan menggunakan grinder. Pembuatan pakan protein mikropartikel yaitu dimulai dengan tepung ikan dan bungkil kedelai dihaluskan menggunakan grinder, kemudian sebagian bungkil kedelai dan tepung ikan yang telah dihaluskan masing-masing dibuat mikropartikel dengan perbandingan 50:200:1 (50 $\mathrm{g}$ bahan dilarutkan dengan $200 \mathrm{ml}$ aquades dan 1 $\mathrm{ml}$ virgin coconut oil (VCO) dan dipapar dengan menggunakan gelombang ultrasonik yaitu ultrasound transducer selama 60 menit (Suthama dan Wibawa, 2016). Bahan pakan tersebut selanjutnya dikeringkan dengan bantuan sinar matahari, diformulasi ransum dengan menggunakan metode trial and error kemudian dibuat pellet.

\section{Perlakuan dan Rancangan Percobaan}

Ayam dipelihara selama 42 hari dikandang battery sehingga konsumsi setiap ekor dapat diukur. Perlakuan dimulai pada saat ayam umur 15 hari yang sebelumnya dilakukan adaptasi pakan perlakuan secara bertahap. Ayam umur $1-8$ diberikan ransum komersial secara ad-libitum, umur 9 hari $70 \%$ ransum komersial dan $30 \%$ ransum perlakuan, umur 10 hari $30 \%$ ransum komersil dan $70 \%$ ransum perlakuan, umur 11 - 14 hari $100 \%$ pakan perlakuan kemudian pada umur 15 hari diberikan ransum perlakuan dengan ditambah Lactobacillus acidophilus 1,2 $\mathrm{ml}$ atau acidifier (asam sitrat) 1,2 $\%$ pada pagi hari. Ransum perlakuan yang digunakan yaitu sebagai berikut:

$\mathrm{T} 0=$ ransum dengan protein $21 \%$ sebagai kontrol.

$\mathrm{T} 1=$ ransum protein non mikropartikel $18 \%+$ Lactobacillus acidophilus $1,2 \mathrm{ml} \quad\left(10^{8}\right.$ $\mathrm{cfu} / \mathrm{ml})$.

$\mathrm{T} 2=$ ransum protein non mikropartikel $18 \%+$ asam sitrat $1,2 \%$.

$\mathrm{T} 3=$ ransum protein mikropartikel $18 \%+$ Lactobacillus acidophilus $1,2 \mathrm{ml}\left(10^{8}\right.$ $\mathrm{cfu} / \mathrm{ml})$.

$\mathrm{T} 4=$ ransum protein mikropartikel $18 \%+$ asam sitrat $1,2 \%$. 
Tabel 1.Komposisi bahan pakan dan kandungan nutrisi ransum percobaan

\begin{tabular}{|c|c|c|c|}
\hline \multirow[b]{2}{*}{ BahanPakan } & \multicolumn{3}{|c|}{ Komposisi } \\
\hline & $\begin{array}{c}\text { Non-mikro Protein } \\
21 \%\end{array}$ & $\begin{array}{l}\text { Non-mikro } \\
\text { Protein } 18 \%\end{array}$ & $\begin{array}{c}\text { Mikro Protein } \\
18 \%\end{array}$ \\
\hline Jagunggiling & 43,2 & 50,8 & 50,8 \\
\hline Bekatul & 20,0 & 20,0 & 20,0 \\
\hline Bungkil Kedelai & 26,4 & 20,7 & - \\
\hline Bungkil Kedelai mikropartikel & - & - & 20,7 \\
\hline Tepungikan & 8,8 & 6,9 & - \\
\hline Tepung ikan mikropartikel & - & - & 6,9 \\
\hline $\mathrm{CaCO} 3$ & 0,6 & 0,6 & - \\
\hline Cangkang Telur & - & - & 0,6 \\
\hline Premiks & 1 & 1 & 1 \\
\hline Total & 100 & 100 & 100 \\
\hline EnergiMetabolis(kkal/kg) & 3020,98 & 3042,69 & 3042,69 \\
\hline Protein $\mathrm{Kasar}^{1}$ & 21,0314 & 18,1452 & 18,1452 \\
\hline Lemak Kasar $^{1}$ & 4,394 & 4,0211 & 4,0211 \\
\hline Serat Kasar ${ }^{1}$ & 5,783 & 5,3180 & 5,3180 \\
\hline Kalsium $^{1}$ & 1,0281 & 0,9284 & 0,9284 \\
\hline Fosfor $^{1}$ & 0,6486 & 0,6169 & 0,6169 \\
\hline Metionin $^{3}$ & 0,4314 & 0,3794 & 0,3794 \\
\hline $\operatorname{Lisin}^{3}$ & 1,3089 & 1,0796 & 1,0796 \\
\hline $\operatorname{Arginin}^{3}$ & 1,4764 & 1,2539 & 1,2539 \\
\hline
\end{tabular}

Keterangan: 1)Hasil analisis bahan pakan di Laboratorium Ilmu Nutrisi dan Pakan, Fakultas Peternakan dan Pertanian Universitas Diponegoro (2018); 2)Perhitungan menggunakan rumus Balton yang dikutip Siswoharjono (1982); 3) Berdasarkan National Research Council (1994).

Rancangan percobaan yang digunakan yaitu rancangan acak lengkap (RAL) dengan 5 kali perlakuan dan 4 kali ulangan, setiap unit percobaan terdiri dari 8 ekor ayam broiler. Bobot organ limfoid dengan cara menyembelih ayam pada setiap ulangan kemudian dibedah, diambil organ limfoidnya, masing-masing organ limfoid (bursa fabricius, limpa, timus) ditimbang dan dihitung dengan menggunakan rumus.

Bobot Organ Limfoid (\%) $=\frac{\text { Bobot organ limfoid }(\mathrm{g})}{\text { Bobot hidup }(\mathrm{g})} \times 100 \%$

(Bikrisima et al., 2013).

Bobot Karkas (g) = Bobot Hidup - (Kepala, Kaki, Jeroan, Bulu, Darah, Leher)

(Subekti et al., 2012).

Heterofil Limfosit (H/L) dengan cara mengambil sampel darah ayam pada bagian sayap yaitu vena brachialis kemudian di analisis di Laboratorium Kesehatan Hewan, Semarang. Data yang diperoleh dianalisis dengan analysis of variance (ANOVA) pada taraf beda $5 \%$ dan dilanjutkan dengan uji Duncan apabila perlakuan menunjukkan pengaruh nyata.

\section{HASIL DAN PEMBAHASAN}

\section{Pengaruh Perlakuan terhadap Bobot Relatif Timus}

Bobot relatif timus pada $\mathrm{T} 4$ nyata paling tinggi karena menggunakan sumber protein dan $\mathrm{Ca}$ mikropartikel sehingga memudahkan pencernaan protein yang didukung dengan asam sitrat sebagai acidifier yang dapat menekan bakteri patogen karena mampu menciptakan kondisi yang ideal di dalam saluran pencernaan untuk perkembangan bakteri menguntungkan sehingga memudahkan pencernaan dan penyerapan nutrien, kecernaan protein juga meningkat yang memberikan feedback positif terhadap perkembangan organ limfoid terutama timus. Penggunaan protein dan Ca kalsium yang diberi asam sitrat mampu menurunkan jumlah bakteri patogen (Avian, data belum dipublikasikan). Mustafa et al. (2014) melaporkan bahwa asam sitrat dapat menghambat pertumbuhan mikroorganisme patogen di dalam usus halus, mengatur mikroflora usus, meningkatkan pemanfaatan nutrien dan meningkatkan performan. 
Tabel 2. Bobot relatif organ limfoid dan rasio $\mathrm{H} / \mathrm{L}$

\begin{tabular}{cccccc}
\hline Perlakuan & Timus & Limfa & $\begin{array}{c}\text { Bursa } \\
\text { Fabrisius }\end{array}$ & $\begin{array}{c}\text { Rasio } \\
\text { H/L }\end{array}$ & $\begin{array}{c}\text { Bobot } \\
\text { Karkas }\end{array}$ \\
\hline T0 & $0,10^{\mathrm{c}}$ & $0,17^{\mathrm{c}}$ & $0,15^{\mathrm{ab}}$ & 0,13 & $\begin{array}{c}(\mathrm{g}) \\
\text { T1 }\end{array}$ \\
\hline T2 & $0,13^{\mathrm{bc}}$ & $0,20^{\mathrm{bc}}$ & $0,14^{\mathrm{b}}$ & 0,15 & $971,50^{\mathrm{ab}}$ \\
T3 & $0,12^{\mathrm{c}}$ & $0,24^{\mathrm{abc}}$ & $0,12^{\mathrm{b}}$ & 0,15 & $878,75^{\mathrm{bc}}$ \\
T4 & $0,16^{\mathrm{b}}$ & $0,25^{\mathrm{ab}}$ & $0,12^{\mathrm{b}}$ & 0,13 & $786,00^{\mathrm{c}}$ \\
\hline
\end{tabular}

Keterangan: Superskrip berbeda pada kolom yang sama menunjukan perbedaan yang nyata $(\mathrm{P}<0,05)$.

Asupan protein dapat meningkatkan bobot timus dan limfa karena protein merupakan substrat yang penting untuk perkembangan organ kekebalan tubuh. Pertumbuhan dan perkembangan organ limfoid primer, yaitu bursa fabrisius dan timus serta organ limfoid sekunder yaitu limpa, berkaitan dengan associated liymphoid tissue dan kelenjar limpha dipengaruhi oleh ketersedian nutrien, terutama protein (Jamillah et al., 2013). Timus merupakan organ limfoid primer yang berfungsi menghasilkan limfosit T. Perlakuan ransum protein (18\%) mikropartikel ditambah Lactobacillus acidophillus 1,2 $\mathrm{ml}$ (T3), menunjukkan bobot timus lebih tinggi dibanding T0 dan T2 (Tabel 2). Penambahan Lactobacillus acidophilus, pada ransum juga dapat menghambat pertumbuhan bakteri patogen sehingga mampu menstimulir sistem kekebalan tubuh. Menurut Manin (2010) Lactobacillus acidophilus dalam ransum dapat menghambat pertumbuhan mikroorganisme patogen dalam usus, meningkatkan pencernaan serta menetralisir enterotoksin dan menstimulir sistem kekebalan tubuh.

\section{Pengaruh Perlakuan terhadap Bobot Relatif Limfa}

Penggunaan pakan sumber protein dan kalsium mikropartikel dengan Lactobacillus acidophillus atau acidifier belum mampu menurunkan bobot limfa, dengan bobot terendah pada perlakuan kontrol (T0) dan terjadi peningkatan pada perlakuan T1, T2, T3 dan T4. Bobot limfa tertinggi terlihat pada perlakuan pakan protein $18 \%$ mikropartikel dengan asam sitrat (T4) (Tabel 2). Perlakuan T0 dan T1 menggunakan ransum protein nonmikropartikel memiliki bobot limfa lebih rendah dari perlakuan yang menggunakan ransum mikropartikel, karena kecernaan protein tinggi dan jumlah coliform sedikit sehingga tidak menimbulkan cekaman akibatnya mobilisasi seperti calcium binding protein (CaBP) lebih lancar. Scott et al. (1982) menyatakan bahwa asupan protein membantu dalam mekanisme pengangkutan kalsium, karena $\mathrm{Ca}$ diserap bersama protein atau calcium binding protein $(\mathrm{CaBP})$ yang berperan dalam membawa kalsium menuju usus, masuk ke pembuluh darah kemudian menuju jaringan yang membutuhkan.

Perlakuan ransum protein mikropartikel dengan acidifier (T4) memiliki bobot limfa paling tinggi. Menurut Latif et al. (2014) bobot limfa yang normal yaitu $0,129 \%$ dari bobot tubuh. Limpa merupakan organ pertahanan sekunder yang berperan dalam memproduksi sel limfosit serta menahan antigen yang masuk dalam sirkulasi darah. Meningkatnya bobot limfa pada (T4) mengindikasikan bahwa limfa bekerja keras atau kerja limfa menjadi lebih aktif dalam meningkatkan kekebalan tubuh untuk menghasilkan antibodi karena kecernaan protein rendah $(82,11 \%$ pada $\mathrm{T} 0$ vs $78,21 \%$ pada $\mathrm{T} 4)$ sehingga asupan protein yang digunakan untuk terbentuknya antibodi tidak cukup. Natsir (2008) melaporkan bahwa besarnya bobot limfa menandakan banyaknya sel dendritik, akibatnya menghasilkan antigen dan antibodi yang banyak pula. Demikian pula Etriwati et al. (2017) menyatakan bahwa konsistensi dan ukuran limfa yang membesar mengindikasikan bahwa fungsi limfa bertambah atau sedang melakukan perlawanan benda asing dari luar.

\section{Pengaruh Perlakuan terhadap Bobot Relatif Bursa Fabrisius}

Bobot relatif bursa fabrisius tertinggi pada perlakuan ransum protein $18 \%$ mikropartikel dengan asam sitrat (T4) (Tabel 2) dan berbeda dengan perlakuan lain (T1, T2 dan T3). Penggunaan asam sitrat sebagai acidifier memberikan indikasi mampu memperbaiki ketahanan tubuh ayam karena mampu menurunkan patogen $(6,59 \log 10 \mathrm{cfu} / \mathrm{g})$ dan meningkatkan bakteri asam laktat $(10,13 \log 10$ cfu/g) sehingga memperbaiki kondisi pencernaan dan kecernaan protein menjadi meningkat 
(Avian, data belum dipublikasikan). Asupan protein dan kalsium berperan dalam perkembangan organ limfoid, kedua nutrien tersebut diserap dalam usus halus melalui mekanisme calcium binding protein (CaBP). Asupan protein berperan dalam mekanisme pengangkutan kalsium yang disebut calcium binding protein (CaBP) (Syafitri et al., 2015). Bobot bursa yang lebih tinggi menunjukan bahwa ransum protein dan kalsium mikropartikel dengan tambahan asam sitrat mampu mempertahankan ketahanan tubuh ternak lebih baik.

Hal tersebut menggambarkan bahwa bursa fabrisius tidak bekerja terlalu keras untuk menghasilkan limfosit B dalam melakukan perlawanan terhadap patogen atau benda asing yang masuk kedalam tubuh. Disisi lain, limfa berhasil mengambil alih fungsi bursa fabrisius sehingga nilai rasio $\mathrm{H} / \mathrm{L}$ rendah karena limfa merupakan respon imun utama yang dapat menyaring antigen dari darah yang telah berikatan dengan limfosit (Tabel 2). Jamillah et al. (2013) menyatakan bahwa pemberian asam sitrat mampu memperbaiki ketahanan tubuh yaitu dilihat dari peningkatan bobot bursa fabrisius dan penurunan nilai rasio heterofil-limfosit. Demikian pula Abdelaziz et al. (2018) menyatakan bahwa bursa fabrisius yang memiliki peran penting yaitu diferensiasi limfosit $\mathrm{B}$, selain itu juga mampu memproduksi antibodi lokal.

\section{Pengaruh Perlakuan terhadap Nilai Rasio Heterofil-Limfosit}

Nilai rasio $\mathrm{H} / \mathrm{L}$ rendah yang menggambarkan bahwa ketahanan tubuh ayam baik. Rasio H/L merupakan indikator terjadinya cekaman pada unggas, makin tinggi nilai rasio tersebut maka semakin tinggi pula tingkat cekaman dan sebaliknya (Kusnadi, 2009). Perlakuan T4 dengan nilai rasio $\mathrm{H} / \mathrm{L}$ rendah karena tingkat cekaman yang dialami oleh ayam rendah akibat dari pemberian asam sitrat mampu menurunkan patogen $(6,59 \log 10 \mathrm{cfu} / \mathrm{g})$ dan meningkatkan total bakteri asam laktat (BAL) $(10,13 \log 10 \mathrm{cfu} / \mathrm{g})$ dalam saluran pencernaan (Avian, data belum dipublikasikan), sehingga ketahanan tubuh ayam meningkat ditandai dengan menurunnya rasio $\mathrm{H} / \mathrm{L}$ (Tabel 2).

Nilai rasio heterofil/limfosit tidak secara signifikan dipengaruhi oleh perlakuan dan dengan konsumsi rendah. Menurut Apriliyani et al. (2013) nilai rasio $\mathrm{H} / \mathrm{L}$ yaitu 0,2 (rendah), 0,5 (normal) dan 0,8 (tinggi). Heterofil memiliki fungsi menghancurkan benda asing melalui fagositosis, heterofil juga termasuk dalam respon imun non spesifik karena sistem imun membatasi penyebaran patogen sebelum mencapai sistem kekebalan spesifik yaitu limfosit (Arifudin et al., 2018). Cekaman yang dialami ternak baik dalam jangka panjang maupun pendek mempengaruhi kadar limfosit, semakin tinggi nilai rasio $\mathrm{H} / \mathrm{L}$ merupakan indikasi semakin tinggi tingkat cekaman. Aengwanich (2007) menyatakan bahwa apabila nilai rasio $\mathrm{H} / \mathrm{L}$ dalam sirkulasi darah meningkat berarti glukokortikoid yang dilepaskan dalam jumlah besar, yaitu pada saat ayam dalam kondisi stres yang menyebabkan meningkatnya pelepasan heterofil.

\section{Pengaruh Perlakuan terhadap Bobot Karkas}

Bobot karkas pada penelitian ini diketahui bahwa perlakuan menunjukan perbedaan nyata $(\mathrm{P}<0,05)$ (Tabel 2). Bobot karkas ayam broiler pada penelitian ini tidak sejalan dengan kecernaan protein terutama pada perlakuan T3 dan T4 yang memiliki kecernaan protein yang lebih tinggi dibanding dengan $\mathrm{T} 1$ dan T2, namun pada T3 dan T4 justru menghasilkan bobot karkas yang rendah, meskipun ketahanan tubuhnya baik. Kondisi ini memberikan indikasi bahwa ransum protein mikropartikel yang ditambah Lactobacillus acidophilus atau acidifier belum mampu memberikan bobot karkas yang sama dibanding ayam yang diberi ransum kontrol. Sebaliknya, penggunaan ransum protein $21 \%$ sebagai kontrol (T0) menghasilkan bobot limfa yang baik meskipun bursa fabrisius rendah namun, kecernaan proteinnya tinggi sehingga bobot karkas yang dihasilkan juga meningkat.

Hasil penelitian Varianti et al. (2017) menyatakan bahwa protein ransum yang dicerna digunakan untuk pembentukan daging sehingga bobot badan akan meningkat dan bobot karkas tinggi. Kecernaan protein pada perlakuan protein $21 \%$ (T0) meningkat karena kandungan protein tinggi dibanding dengan perlakuan protein $18 \%$ $(\mathrm{T} 1, \mathrm{~T} 2, \mathrm{~T} 3, \mathrm{~T} 4)$. Namun, kecernaan protein pada perlakuan protein mikropartikel $18 \%(\mathrm{~T} 3, \mathrm{~T} 4)$ lebih tinggi dibanding dengan perlakuan protein non mikropartikel $18 \% \quad(\mathrm{~T} 1, \mathrm{~T} 2)$. Hal ini dikarenakan meningkatnya kecernaan protein dipengaruhi oleh ukuran partikel, semakin kecil ukuran partikel mempermudah kerja enzim dalam saluran pencernaan (Mingbhin et al., 2015).

Bobot karkas pada T3 dan T4 yang menggunakan ransum protein dan kalsium mikropartikel $18 \%$ dengan Lactobacillus acidophilus atau acidifier termasuk rendah 
meskipun ketahanan tubuhnya baik dan kecernaan protein termasuk tinggi. Ini ditunjang oleh konsumsi protein 21\% lebih tinggi dan dimungkinkan adanya degradasi protein akibat dari tingginya massa kalsium daging pada T3 $(11,16)$ dan T4 $(11,67)$ dibanding T0 $(10,29)$ yang lebih rendah (Iqza, data belum dipublikasikan). Menurut Suthama et al. (1991) kemampuan pertumbuhan daging ditentukan oleh sintesis dan degradasi protein, adanya kalsium bentuk ion sebagai aktivator calcium activated neutal protease (CANP) menyebabkan terjadinya degradasi protein sehingga deposisi protein berkurang dan masa kalsium daging tinggi.

\section{KESIMPULAN}

Kesimpulan penelitian yaitu pemberian ransum mikropartikel dengan protein $18 \%$ yang ditambah acidifier mampu memperbaiki ketahanan tubuh berdasarkan penurunan rasio $\mathrm{H} / \mathrm{L}$, peningkatan bobot relatif bursa dan bobot timus namun belum mampu menurunkan bobot limfa dan meningkatkan bobot karkas.

\section{DAFTAR PUSTAKA}

Abdelaziz, K. T., D. C. Hodgins., A. Lammers., T. N. Alkie and S. Sharif. 2018. Effect of early feeding and dietary intervention on development of ly,mphoid organs and immune competence in neonatal chickens. J. Vet. Immunol. Immunopath. 201: $1-11$.

Aengwarich, W. 2007. Effect of dexamethasone on physlological changes and productivi performans in broiler. Asian Journal of Animal and Vetenary Advances 2 (3): $157-161$.

Apriliyani, F., N. Suthama dan H. I. Wahyuni. 2013. Rasio heterofil limfosit dan bobot relatif bursa fabricius akibat kombinasi lama pencahayaan dan pemberian porsi ransum berbeda pada ayam broiler. Anim. Agric. J. 2 (1): 393 - 399.

Arifudin, K., T. A. Sarjana., R. Muryani., L. D. Mahfudz., D. Sunarti., W. Sarengat dan I. P. Angkeke. 2019. Zonation in closed house affecting ammonia emission, immune system and broiler performance in the dry season. International Conference of Animal Science and
Technology (ICAST). IOP Conf. Series: Earth and Environmental Science 247.

Etriwati, D. Ratih., E. Handharyani dan S. Setiyaningsih. 2017. Studi hispatologi limpa dan bursa fabricius ayam berpenyakit tetelo (Newcastle Disease) pada kasus lapang. J. Vet. 8 (4): $510-$ 515.

Jamilah, N. Suthama dan L. D. Mahfudz. 2013. Performa produksi dan ketahanan tubuh broiler yang diberi pakan Step Down dengan penambahan asam sitrat sebagai acidifier. J. Ilmu Ternak dan Vet. 18 (4): $251-257$.

Kusnadi, E. 2009. Perubahan maloneldehida hati, bobot relatif Bursa Fabricius dan rasio Heterofil/Limfosit (H/L) ayam broiler yang diberi cekaman panas. Med. Pet. 32 (2): $81-87$.

Latif, I. K., H. M. Majid dan H. Sahar. 2014. Determine the weight of thymus, bursa of fabricius and spleen and its ratio to body weight in some disease broilers. MRSVA $3(1): 8-14$.

Manin, F. 2010. Potensi Lactobacillus acidophilus dan Lactobacillus fermentum dari saluran pencernaan ayam buras asal lahan gambut sebagai sumber pobiotik. J. Ilmiah Ilmu-Ilmu Peternakan 13 (5): 221 -228 .

Mingbin, L.V. Y. Lei, W. Zhengguo, S. An, W. Miaomiao, L. V. Zunzhou. 2015. Effects of feed form and feed particle size on growth performance, carcass characteristics and digestive tract development of broilers. Animal Science 1 (3): 252-256.

Mustafa, M. A. G. H., M. Sulaiman dan M. Salahaddin. 2014. Effect of acetic acid added to drinking water of two broiler strains on performance and small intestine histological. J. Diyala Agric. Sci. 6 (1): $1-8$.

Natsir, M. H. 2008. Pengaruh penggunaan kombinasi asam sitrat dan asam laktat cair dan terenkapsulasi sebagai aditif pakan terehadap persentase karkas dan berat organ dalam ayam pedaging. J. 
Ilmu dan Teknologi hasil Ternak 3 (2): $17-22$.

Scott, M. L., M. C. Nesheim, and R. J. Young. 1982. Nutrition of the Chicken Edition M. L. Scott Associate. Ithaca, New York.

Setiawati, D., B. Sukamto dan H. I. Wahyuni. 2016. Pengimbuhan enzim fitase dalam ransum ayam pedaging meningkatkan pemanfaatan kalsium untuk pertumbuhan tulang dan bobot badan J. Vet. 17 (3): $456-464$.

Suthama, N., K. Hayashi., M. Toyomizu dan Y. Tomita. 1991. Interaction of exogenous thyroxine and dietary protein levels on growth and muscle protein metabolism in broiler chickens. Jpn. Poult. Sci. 28 (1): 1 -10 .

Suthama, N dan P. J. Wibawa. 2016. Digestibility evaluation of microparticle protein derived from fish meal and soybean meal in broiler chicken. Seminar International:
The Sixth International Conference on Suatainable Animal Agriculture for developing Counries. Malang 19 - 21 October 2016. Pp. $214-216$.

Syafitri, Y. E., V. D. Yunianto dan N. Suthama. 2015. Pemberian ekstrak daun beluntas (Pluchea indica Less) dan klorin terhadap massa kalsium dan massa protein daging pada ayam broiler. J. Anim. Agric. 4 (1): 155-164.

Varianti, N. I., U. Atmomarsono dan L. D. Mahfudz. 2017. Pengaruh pemberian pakan dengan sumber protein berbeda terhadap efisiensi penggunaan protein ayam lokal persilangan. Agripet 14 (2): $76-83$.

Yendy, S. A., I. Mangisah, dan B. Sukamto. 2014. Pengaruh penambahan asam sitrat dalam ransum sebagai acidifier terhadap retensi kalsium dan fosfor itik jantan lokal. Anim. Agric. J. 3 (1) : $70-78$. 